\title{
1 Trench migration and slab buckling control the formation of the
}

(1) Helmholtz-Zentrum Potsdam GFZ - Deutsches GeoForschungsZentrum, Germany,

(2) Universität Potsdam, Institut für Geowissenschaften, Germany,

(3) GEOMAR Helmholtz Centre for Ocean Research Kiel, Germany,

(4) Geological Institute, Department of Earth Sciences, Swiss Federal Institute of Technology (ETH), Zurich,

${ }^{*}$ Corresponding author: Michaël Pons (ponsm@gfz-potsdam.de)

\section{Abstract}

The formation of the Central Andes dates back to $50 \mathrm{Ma}$, but its most pronounced phase, including the growth of the Altiplano-Puna Plateau and pulsatile tectonic shortening phases, occurred within the last $25 \mathrm{Ma}$. The reason for this evolution remains unexplained. Using geodynamic numerical modeling we infer that the primary cause of the pulses of tectonic shortening and growth of Central Andes is the changing geometry of the subducted Nazca plate, and particularly the steepening of the mid-mantle slab segment which results in a slowing down of the trench retreat and subsequent shortening of the advancing South America plate. This steepening first happens after the end of the flat slab episode at $225 \mathrm{Ma}$, and later during the buckling and stagnation of the slab in the mantle transition zone. The Intensity of the shortening events is enhanced by the processes that mechanically weaken the lithosphere of the South America plate, which were suggested in previous studies. These processes include delamination of the mantle lithosphere and weakening of the foreland sediments. Our new modeling results are consistent with the timing and amplitude of the deformation from geological data in the Central Andes at the Altiplano latitude. 


\section{Introduction}

The Central Andes is a natural laboratory to study inherent tectonics and geodynamics processes. Although the subduction of the oceanic Nazca plate below the South American plate has been ongoing since $\sim 200 \mathrm{Ma}$, most of the Andean orogen formed in the last $\sim 15 \mathrm{Ma}$. The Central Andes hosts the second largest plateau in the world, the Altiplano-Puna plateau, which is on average $\sim 4 \mathrm{~km}$ high and extends over an area of $500,000 \mathrm{~km}^{2}$ (Fig. 1ab). This unusually short growth time is recorded by the geological shortening rate (Oncken et al., 2006, 2012). A few different mechanisms are thought to have contributed to the shortening of the Central Andes at the Altiplano latitude $\left(\sim 21^{\circ} \mathrm{S}\right)$ :

- $\quad$ The westward absolute motion of the South American plate $(\sim 2 \mathrm{~cm} / \mathrm{yr})$ provides the main shortening force (Silver et al., 1998; Sobolev \& Babeyko, 2005; Martinod et al., 2010; Husson et al., 2012), where the relative velocity between the trench and the plate determines the tectonic stress regime (Lallemand et al., 2005; Funiciello et al., 2008; Lallemand et al., 2008; Holt et al., 2015). Slower trench migration as a consequence of the slab anchoring in the lower mantle over the last $40 \mathrm{Ma}$ (Faccenna et al., 2017; Schepers et al., 2017) is argued to have initiated the shortening in the Central Andes.

- A high interplate friction of $\sim 0.05-0.07$ due to the low supply of sediments at the trench promotes the stress transfer from the slab to the overriding plate, increasing the shortening rate (Lamb \& Davis, 2003; Sobolev \& Babeyko, 2005; Sobolev et al., 2006; Gerbault et al., 2009; Heuret et al., 2012; Tan et al., 2012; Cosentino* et al., 2018; Horton 2018; Muldashev \& Sobolev, 2020; Brizzi et al., 2020).

- The weakening of the continental lithosphere that results from the eclogitization of the mafic lower crust (Sobolev \& Babeyko, 1994; Babeyko et al., 2006) and the delamination of the lithospheric mantle (Kay \& Mahlburg Kay, 1993 ; Beck \& Zandt, 2002 ; Beck et al., 2015) helps strain to localize and thereby increases the shortening. 
- Weak sediments in the foreland help initiate simple shear shortening by starting the underthrusting of the Brazilian Cratonic shield (Allmendinger \& Gubbels, 1996; Allmendinger et al., 1997; Kley, 1999; Babeyko \& Sobolev, 2005; Gao et al., 2021; Liu et al., 2022).

Despite the multitude of proposed shortening mechanisms, none adequately explain the evolution and variability of deformation in the Central Andes during the last $\sim 35 \mathrm{Ma}$ (Fig. 1C). However, the quality of the shortening rate compilation from Oncken et al (2006-2012, Fig. 1c) offers a solid base to investigate this problem through geodynamic models. Although the data may carry intrinsic uncertainties from using different measurement methods, it shows a systematic consistency in shortening amplitudes across time and latitude.

Shortening rates along the Altiplano section at $21^{\circ} \mathrm{S}$ are the most temporally resolved and suggest four different phases of deformation in the last $\sim 50 \mathrm{Ma}$ (Fig. 1C). Between $\sim 50$ to 33 $\mathrm{Ma}$ (Phase 1), the shortening rate linearly increased to $\sim 3.5 \mathrm{~mm} / \mathrm{yr}$ before suddenly escalating at $\sim 33 \mathrm{Ma}$ to $\sim 8 \mathrm{~mm} / \mathrm{yr}$. From $\sim 33$ to $15 \mathrm{Ma}$ (Phase 2), the shortening rate fluctuated in a range between $\sim 4$ and $\sim 7 \mathrm{~mm} / \mathrm{yr}$ that eventually narrowed to $\sim 6 \mathrm{~mm} / \mathrm{yr}$. From $\sim 15$ to $7 \mathrm{Ma}$ (Phase 3), shortening pulsed to a maximum of $\sim 11 \mathrm{~mm} / \mathrm{yr}$ before dropping back to $\sim 5 \mathrm{~mm} / \mathrm{yr}$. From $\sim 7$ Ma to present day (Phase 4) the shortening rate again pulsed to a maximum of $\sim 16 \mathrm{~mm} / \mathrm{yr}$ before dropping back to the $\sim 8 \mathrm{~mm} / \mathrm{yr}$ seen at present-day.

Utilizing high-resolution geodynamic models, with buoyancy-driven subduction, and validating them through geological shortening data from the Central Andes, this study sheds light on a new mechanism that provides an explanation for the variability of the shortening rate. The models additionally address the gap in deformation intensity between 10 and $4 \mathrm{Ma}$ and the decline in intensity to present-day levels. Our results suggest that a complex interaction between the oceanic and continental plates controls the timing and variability of the deformation in the Central Andes since the Oligocene. 

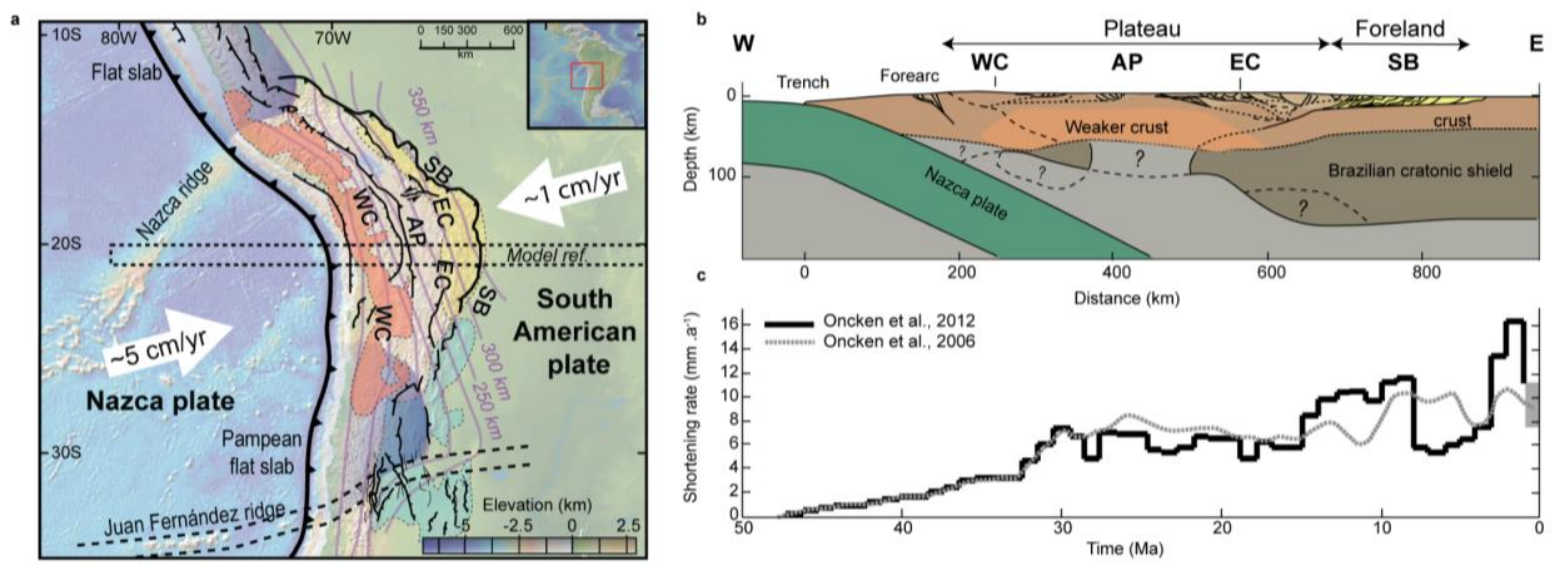

Fig. 1 a Structural map of the Central Andes (modified from Oncken et al., 2006), overlain with the extent of the active magmatic arc (red) and the foreland areas with thin-skinned (yellow) and thick-skinned (light-blue) deformation. Blue shaded areas indicate the neighbouring flat-slab regions. White arrows show the present day absolute plate velocity (Becker et al., 2015). b Schematic tectonics of the Altiplano transect at $21^{\circ} \mathrm{S}$ (dashed rectangle in a), modified from Oncken et al. (2006) and Armijo et al. (2015). The question mark indicates an unclear presence of the lithosphere. $\mathbf{c}$ Estimated shortening rate evolution of the Altiplano transect. WC: Western Cordillera; AP: Altiplano Plateau; EC: Eastern Cordillera; SB: Subandean Ranges.

\section{Results}

Numerical model set up. We used the finite element software ASPECT (Bangerth et al., 2021) to develop a visco-plastic subduction model S1 that simulates ductile and brittle deformation. Subduction is initiated by prescribing an oceanic plate velocity of $7 \mathrm{~cm} / \mathrm{yr}$ in the first 6.5 My, which represents the plate velocity between 35-30 Ma (Sdrolias and Müller, 2006). Then, the oceanic plate freely sinks through the mantle due to slab pull. The continental plate is prescribed with a trenchward velocity of $2 \mathrm{~cm} / \mathrm{yr}$, corresponding to the average plate velocity during the last $40 \mathrm{Ma}$. As gaps in the Andean volcanic activity at $~ 35$ Ma suggest a phase of flat slab subduction (Barazangi \& Isacks, 1976; Ramos \& Scientific, 2002; Ramos \& Folguera, 2009), we initialized the model with a flat-subduction stage (Fig. 2a). After initialization (Fig. $2 b$ ), the flat slab segment is $\sim 250 \mathrm{~km}$ long at $\sim 100 \mathrm{~km}$ depth, similar to the current Pampean flat slab (Marot et al., 2014). 
The geometry of the continental plate is based on structural reconstructions and crustal balance estimations during the Oligocene (Hindle et al., 2005; Sobolev et al., 2006; Armijo et al., 2015). For the shortening analysis, we differentiated two continental domains: the orogen and the thicker foreland. We used an oceanic lithospheric thickness consistent with a $40 \mathrm{My}$ old (Maloney et al., 2013) plate near the trench (Turcotte et al., 2002). We assumed a steadystate geotherm for the lithosphere and an adiabatic temperature profile for the asthenosphere and let the temperature re-equilibrate during initialization.

Four key ingredients are used to simulate plate interaction in Model S1: First, a highresolution $(1 \mathrm{~km})$ visco-plastic subduction interface with a low effective friction $(0.05)$, causing

107 the brittle-ductile transition to occur at $\sim 45 \mathrm{~km}$ depth. Second, the implementation of the Gabbro-Eclogite-Stishovite phase transitions for the oceanic crust, and the Olivine -

Wadsleyite-Ringwoodite-Post Spinel transitions for the asthenosphere and lithospheric mantle

110 (Arredondo \& Billen, 2016, 2017; Faccenda \& Dal Zilio, 2017). Third, the use of a deformable

111 mesh to simulate the topography (see Methods for details). Fourth, self-consistent subduction

112 that is buoyancy-driven.

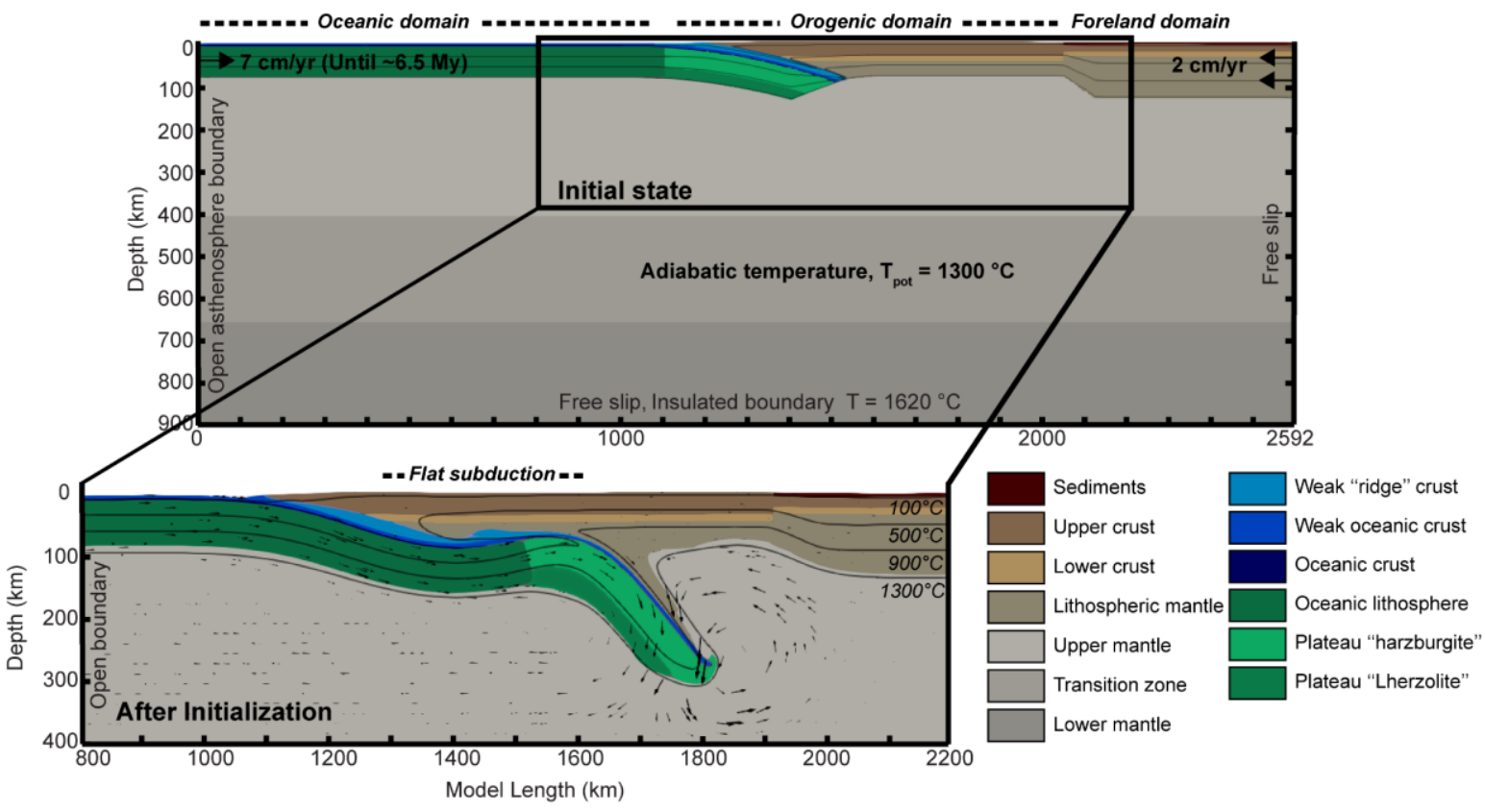


Fig. 2 Model setup. $T_{\text {pot }}$ is the mantle potential temperature. a shows the initial state of the model. $\mathbf{b}$ is the zoom-in area of plate interface during the initial flat slab subduction stage.

(1)

Numerical model results. From $\sim 7$ to $\sim 11$ My (Fig. 3a), subduction evolves dynamically. The slab steepens and accelerates, slowing down the trench retreat. Part of the continental mantle starts delaminating as plastic strain localizes in the top of the continental crust. During this time, topographic uplift is restricted to the Central domain. At $10 \mathrm{My}$, the block of continental lithosphere consisting of eclogitized lower crust and mantle delaminates and sinks with the slab. At $\sim 10.5 \mathrm{My}$, the slab velocity decreases as trench retreat reinitiates. From $\sim 11$ to $\sim 20$ My (Fig. 3b), relatively fast slab rollback continues as the slab sinks into the transition zone. At $\sim 18 \mathrm{My}$, the slab reaches the lower mantle but does not immediately penetrate into it, instead it is deflected and slowly traverses horizontally along the $660-\mathrm{km}$ phase transition. At 20 My, the slab buckles by folding twice to the west and to the east at the transition zone as the trench continues to retreat.

At 23.5 My, the upper mantle slab-segment steepens and halts trench retreat (hereby referred to as trench blockage). At this time, slab velocity increases and strain localizes on the previous faults and in the eastern orogenic domain. Simultaneously, the lithospheric mantle successively delaminates in the east as the deformation intensifies and migrates west towards the foreland (Fig. 3c). Underthrusting of the cratonic shield initiates at $\sim 26$ My during the delamination of the mantle lithosphere. The eastern domain uplifts from 20 to $24 \mathrm{My}$, then slightly subsides at $24 \mathrm{Ma}$.

From $\sim 25$ to $\sim 31$ My the topography significantly uplifts and reaches elevations similar to the present-day (Fig. 4). At 29 My, active deformation in the foreland decreases and trench retreat reinitiates as the new slab segment reaches the lower mantle transition trenchward of the older, stalled, slab segment. After this time, topography no longer significantly changes (Fig. 4). At $\sim 30$ My, the slab buckles a second time followed by another stage of trench 
141 blockage at $\sim 35 \mathrm{My}$ (Fig. 3d) as the slab steepens and accelerates. By $\sim 33.5 \mathrm{My}$, the cratonic

142 shield has re-initiates underthrusting beneath the orogenic domain. At $~ 37.5$ My foreland

143 deformation becomes less efficient and the mantle wedge starts to delaminate as trench

144 retreat reinitiates. Overall, the trench retreats $\sim 340 \mathrm{~km}$, the orogen shortens $\sim 200 \mathrm{~km}$ and

145 because of underthrusting the foreland shortens by $105 \mathrm{~km}$ (Fig. 7ab, movie S1).

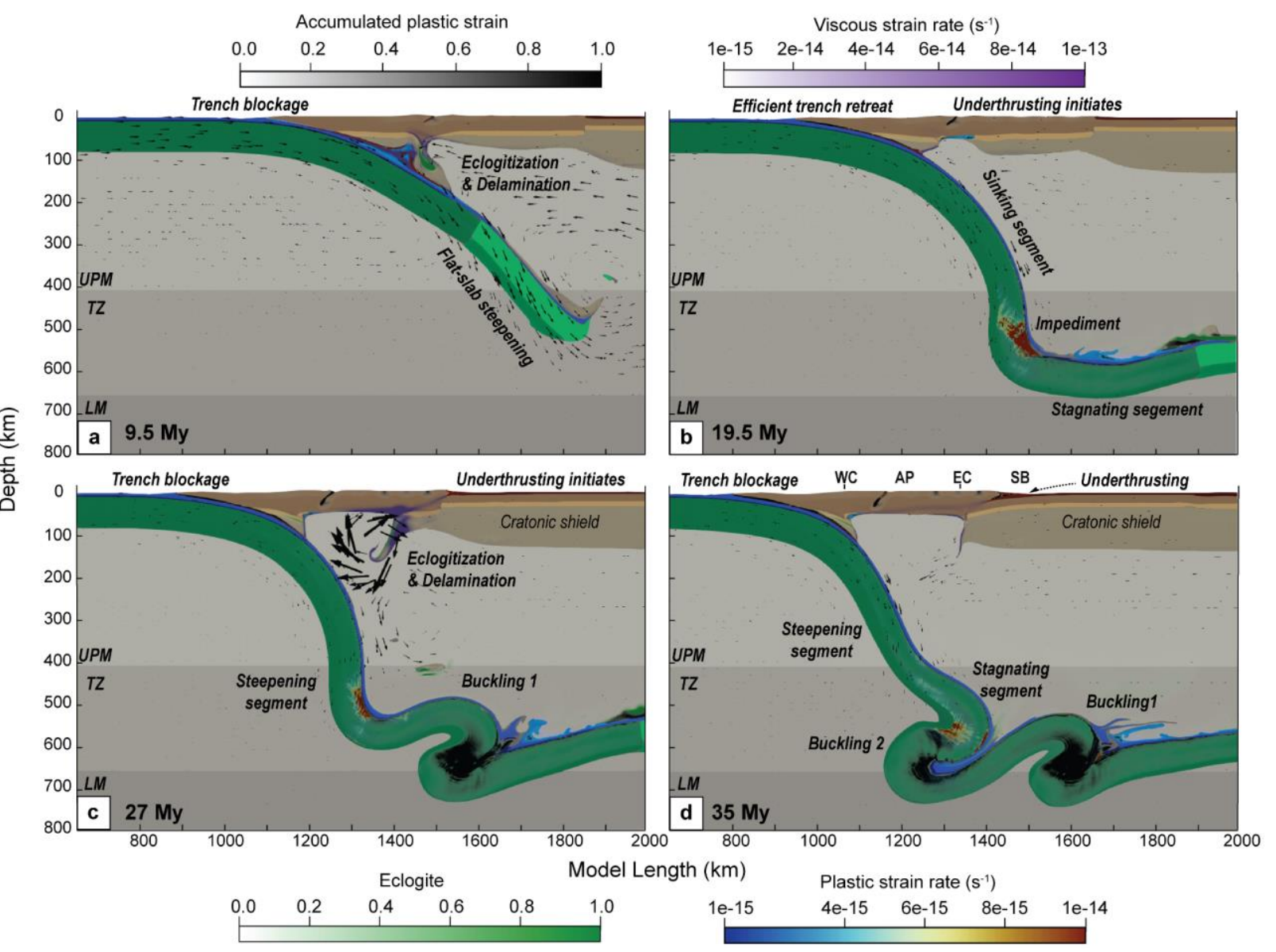

Fig. 3 Evolution of the subduction model S1. UPM, TZ and LM are the upper mantle, transition zone and lower mantle, respectively. a The steepening of the slab is associated with the continental lithospheric mantle removal. $\mathbf{b}$ The slab freely sinks and flattens at lower mantle transition. c The slab buckles, the continent delaminates, the deformation migrates eastward and the foreland underthrusts. d The slab buckles a second time and the foreland underthrusts. 
We have also ran the 5 alternative simulations to Model S1: (i) three models with variable interplate friction coefficient $(0.015,0.035,0.06$; model S2a-c, supplementary Fig. 2, 3, movie

157 S2a-c); (ii) one model without eclogitization of the lower crust to illustrate its importance for the weakening of the overriding plate and for the localization of the deformation (model S3, supplementary Fig. 2, 5, movie S3); and (iii) one model to evaluate the importance of higher heat flow and lower crustal viscosity related to partial melting (model S4; supplementary Fig. $2,5,6$, movie S4). The description of these models is detailed in the Supplementary material 162 (see supplementary information).

\section{Discussion}

Our results suggest that the timing of the shortening events is a direct consequence of the interaction between the buckling subducting plate and the weakened overriding plate. We distinguish four notable deformation phases that correspond in amplitude, timing and space to the shortening rate from the geological compilation (Onken et al., 2012). Overall, deformation migrates across the orogenic domain to the eastern foreland.

Phase I : Central domain deformation ( 6.5 to $\sim 11 \mathrm{My}$, Fig. 4): Plastic strain is localized in the Central domain due to flat slab steepening and the partial removal of the lithosphere.

Phase II : Eastern Cordillera domain deformation ( 11 to 20 My, Fig. 4): Distributed plastic strain slowly accumulates in the east. No significant deformation is observed in the continent due to efficient trench retreat.

Phase III : Deformation migrates from the Eastern Cordillera to the foreland domain ( 20 to 29 My, Fig. 4): Strain intensifies in the Eastern Cordillera domain and migrates to the foreland, where the Brazilian Cratonic shield starts to underthrust below the orogen. The delamination follows this migration.

Phase IV : Foreland domain deformation ( 29 to 38 My, Fig. 4): Underthrusting of the shield slows down. At 33.5 My, it re-accelerates until 35 My before decelerating until $38 \mathrm{My}$. 
The compressive stress generated by the difference of velocity between the trench and

181 the overriding plate is accommodated in one of two ways: 1) orogenic shortening, 2)

182 underthrusting of the foreland. The effectiveness of deformation localization depends on the 183 strength of the overriding plate and the interplate coupling. Here, we discuss the key 184 processes that affect the strength of the overriding plate, the subduction and deformation 185 dynamics of the slab, and, finally, the interaction between the two plates.

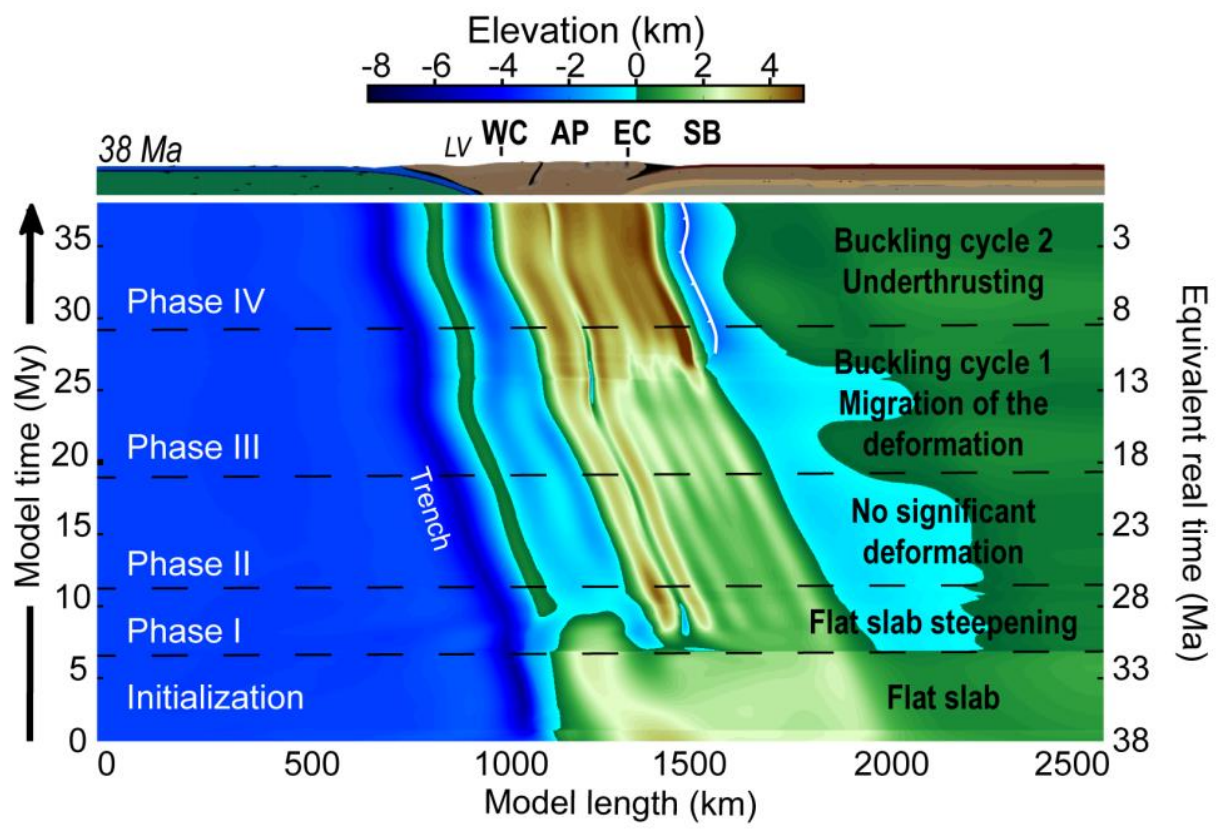

186

187

188

189

190

191

192

193

194

195

196

197

Fig. 4 Topographic evolution of the reference model, with deformation phase timings shown using dotted black lines, and key features of each phase are written in black. Lv is for Longitudinal Valley.

\section{Overriding plate}

Delamination. Extensive lithospheric delamination is known to have taken place under the Altiplano-Puna plateau (Kay \& Kay, 1993; Beck \& Zandt, 2002; Beck et al., 2015) and contributed to present-day elevations (Garzione et al., 2006, 2008, 2017; Wang et al., 2021).

This process is thought to be the result of the eclogitization of the mafic lower crust and lithospheric mantle, which is likely facilitated by the hydration of the sub-lithosphere from the 200 Ma subduction history (Babeyko et al., 2002, 2006), and thick ( 45 km) initial crust at 
30 Ma (Hindle et al., 2005; Sobolev et al., 2006; Armijo et al., 2015). Model S3 demonstrates

199 that without eclogitization delamination and shortening are inhibited (supplementary Fig. 2).

200 Moreover, the lithospheric removal due to eclogitization leads to a localization of deformation

201 and subsequent weakening in the overriding plate. Nevertheless, model S4 shows that a very

202 weak orogenic domain localizes too much deformation in the orogen and does not guarantee

203 the migration of the deformation to the foreland (supplementary Fig.5).

204 Due to flat slab steepening in Phase I, we observe two delamination stages after the first 205 lithospheric removal of the overriding plate. First, the initial removal exposes the crust at the 206 western edge that is directly in contact with the asthenosphere, thereby increasing its 207 temperature and decreasing the viscosity at its base. As a result, the lower crust delaminates 208 faster in the west, causing it to asymmetrically drip to the east (i.e., Stage 1 in Fig. 5a). The 209 pure shear deformation localizes in the orogenic domain until delamination is complete.

210 Second, when the viscous deformation of the orogen connects with the plastic deformation of 211 its foreland at $26 \mathrm{My}$, the foreland underthrusts beneath the orogen due to weak sediments.

212 This results in orogenic thickening and a switch from pure shear to simple shear shortening.

213 Consequently, deformation migrates to the east causing delamination to accelerate (Stage 2 214 in Fig. 5b).

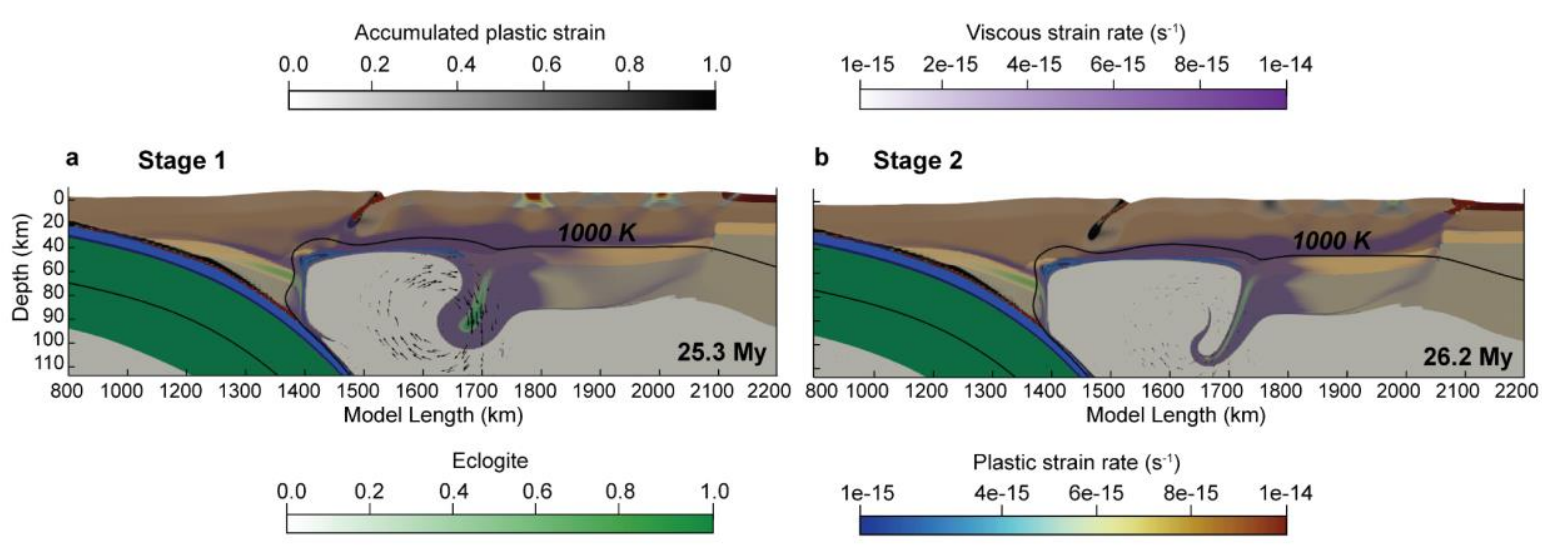

Fig. 5 showing the two stages of delamination. a Stage 1: Asymmetric delamination, 217 facilitated by the heating and thickening of the continental crust. b Stage 2: Delamination 

acceleration, accompanied by migration of the deformation to the foreland and initiation of the foreland underthrusting.

Mechanical weakening of the foreland sediments. In the Altiplano, the presence of

222

223

224 weak sediments is the key factor in switching deformation from pure to simple shear at $\sim 10$ Ma. Simple-shear shortening is associated with higher strain localization over fewer faults and the formation of deep low-angle detachments. In the foreland, these faults are situated at the base of the sediment cover and are characteristic of the thin-skin deformation style. Porous sediment layers, in particular the paleozoic layers (Allmendinger and Gubbels, 1996), may have accumulated enough fluids at the front of the orogen to reduce their frictional strength to $\sim 0.05$ or less and initiate the underthrusting of the Brazilian cratonic shield (Babeyko et al., 2006).

This thin-skin style of deformation is often opposed to the thick-skin style, where strain is more distributed throughout the domain and may involve basement rock. At the latitude of the Puna, thick-skin deformation resulted in a final shortening amount much lower than in Altiplano ( 150 km versus 300 km; Kley et al., 1999; Sobolev and Babeyko, 2005; Babeyko \& Sobolev, 2005). This shortening difference suggests that forces were accommodated elsewhere, which we suggest to be the retreating trench.

Commonly, thick-skin deformation is thought to result from the reactivation of pre-existing normal faults that formed in past extensional events (Carrera and Muñoz, 2013). The weak faults localize strain faster and enhance the shortening magnitude. However, their reactivation could also compete against an efficient switch from pure to simple shear deformation.

In the reference model, underthrusting takes place in two stages. The first stage happens during trench blockage at $20.5 \mathrm{My}$, causing the deformation to migrate to the foreland. When the active brittle shear zone, from the failure of the foreland sediments, connects to the ductile shear zone accommodating the on-going delamination underthrusting becomes more efficient. The delamination also facilitates the underthrusting of the Brazilian cratonic shield that meets 
less resistive forces. Underthrusting of the shield forces the upper crust to viscously flow and

246 thicken. The topography uplifts, reaching present-day elevations ( 4 km) at $\sim 31 \mathrm{My}(\sim 7 \mathrm{Ma}$

247 ago). A second stage of underthrusting occurs in the last $\sim 4 \mathrm{Ma}$ when the trench again becomes blocked, but this event does not significantly change the topography (Fig. 4).

\section{Subducting plate}

While the absolute motion of the South American plate provides the main force (Martinod et al., 2010; Husson et al., 2012) for the tectonic shortening, the magnitude of the compressive stress in the South American plate margin is determined by the the resistance of the Nazca plate (i.e., by the ability of the trench to retreat Lallemand et al., 2005; Funiciello et al., 2008; Lallemand et al., 2008; Holt et al., 2015). In the central Andes, the trench has migrated west over the last $\sim 40 \mathrm{Ma}$ as a result of the rollback and subsequent sinking of the bending slab in the asthenosphere, as well as the forced trench retreat from the excess velocity of the overriding plate (Schepers et al., 2017). Recent studies have proposed that the trench velocity can also be affected by deep subduction dynamics (Faccenna et al., 2017; Briaud et al., 2020). In this section, we discuss the implications of these subduction dynamics.
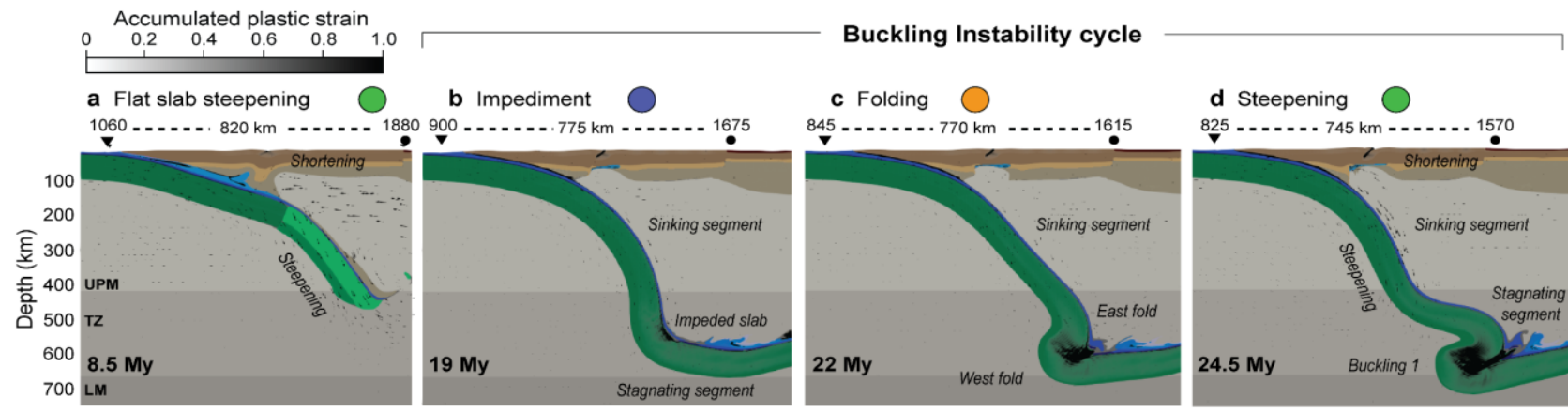

Fig. 6 Subduction dynamics. Black triangle and circle indicate the position of the trench and the foreland edge, respectively. Colored circles indicate slab evolution in figure 8. a Steepening and sinking of the flat slab leads to an increase of plate velocity and slows down the trench. $\mathbf{b}$ The slab front is impeded in the viscous lower mantle transition zone. c The stagnant slab folds, meanwhile the trench retreats. $\mathbf{d}$ The slab folds but the lack of obstacle leads to its steepening. 
Flat slab steepening. The cause of flat subduction is still debated. It likely results from 270 the shallowing of the slab from long lasting subduction, as well as greater buoyancies related 271 to the Juan Fernandez ridge (Schellart, 2020; Schellart \& Strak, 2021) that has migrated to 272 the south in the last 35 Ma (Fig. 1; Yáñez et al., 2001; Bello-González et al., 2018). In this 273 study, we are interested in the consequence of slab steepening after the passage of the ridge. 274 Our models suggest that a flat slab at $\sim 100 \mathrm{~km}$ depth, analogous to the Pampean flat slab, 275 could scrape the base of the lithosphere. Eventually at $\sim 7 \mathrm{My}$, the slab steepens and 276 accelerates as the trench becomes blocked (Fig. 6a). The continental mantle coupled to the 277 flat slab segment is pulled down and viscously accommodates the deformation. When the 278 lower crust eclogitizes, plastic strain localizes in the top portion of the crust, slab steepening then accelerates due to the eclogitization until, eventually, parts of the lithosphere are removed. This flat subduction plays a key role in triggering the initial weakening of the overriding plate, and is facilitated by lower-crustal eclogitization .

Buckling instability cycles. We identified two buckling cycles, at 20 My and at 30 My. Within each cycle, three main events are distinguished that may affect the trench migration 284 rate:

(1) Slab impediment (Fig. 6b) takes place when the slab meets viscous resistance. This is the case when the slab is impeded by the viscous lower mantle at the beginning of a buckling 287 cycle ( 17 My and $\sim 29.5 \mathrm{My}$ ), or before steepening. For instance, when the slab reaches the 288 viscous lower mantle it does not immediately penetrate it. The first slab segment in contact 289 with the lower mantle slows down and viscously resists the new, still sinking, segment. This difference of velocity between the two segments is accommodated through bending in the slab. During these slab impediment events the dip of the slab becomes shallower and the trench continues retreating. This mechanism differs from slab anchoring (Faccenna et al., 
2017), in which the difference of velocity between the two segments is too small to cause the

294 folding of the slab.

295

(2) Slab folding (Fig. 6c) events occur when, after slab impediment, the slab dip flips in 296 the transition zone. The now shallower slab dip enable the trench retreat, though no significant deformation is observed. Each buckling cycle consists of two folding events, the first to the west and the second to the east at $\sim 20,21 \mathrm{My}$ and $\sim 30,33 \mathrm{My}$.

(3) Slab steepening (Fig. 6d) is a drastic event that occurs at the end of a buckling cycle after the second folding event, ( 23.5 My and $\sim 33.5 \mathrm{My})$. Chronologically, the sinking slab meets resistance from the last fold to the east (i.e., Impediment) and bends to the west as for the first folding event. However, the overriding plate has forced the trench to retreat during the previous events, which, prevents the slab from piling up. The slab continues to sink in the transition zone, steepens and accelerates. The trench slows down and blocks the overriding plate that shortens to accommodate the ongoing deformation. When the trench is blocked the horizontal stress in the overriding plate can reach values of $\sim 350 \mathrm{MPa}$ (supplementary Fig. 1, movie S1b). Overall, slab shallowing is associated to periods of trench retreat related to the folding events, whereas slab steepening is associated to periods of trench blockage following folding events folding events.

\section{Interaction between overriding and subducting plates}

311 Interplate coupling. Our models predict that an effective friction of 0.35 to 0.05 is required 312 in the Central Andes to obtain significant deformation that is consistent with previous 313 estimates (Sobolev and Babeyko, 2005; Sobolev et al., 2006). Higher friction values result in 314 lower oceanic-plate velocities. The effective friction is dependent on the sediment thickness 315 at the trench, which at present day may vary from $\sim 0.5 \mathrm{~km}$ to $\sim 2 \mathrm{~km}$ in the Central and 316 Southern Andes, respectively (Lamb and Davis, 2003). This latitudinal variation results from

317 the efficiency at which the surface processes supply sediments to the trench. In the last $\sim 6$ $318 \mathrm{Ma}$, glacial erosion supplied a large amount of sediments to Southern Andes trench. Whereas 
319 in the Central Andes, the internal drainage of the Altiplano-Puna plateau is related to low 320 erosional rates that have contributed to sediment starvation at the trench (Lamb \& Davis, $3212003)$.

322 Slab buckling and overriding plate interaction. The unusual timing of the growth of the 323 Andes results from a sequence of events generated by plate interactions. While subduction dynamics exert a major control on the deformation of the sinking plate by blocking trench migration, the strength of the overriding plate ultimately controls where strain localizes and forces the trench to retreat when it is not blocked. This plate strength is evolving, first, with the passage of the flat slab that may have initially weakened the lithosphere through partial removal of the mantle lithosphere, and through thermal weakening related to crustal exposure near the hotter asthenosphere (Isacks, 1988), and second, by triggering the subsequent delamination (see previous section).

Pulsatile behavior in the deformation of the Nazca plate is observed in paleoelevation reconstructions (Boschman, 2021 ; Garzione et al., 2008), the magmatic activity (Decelles et al., 2009), and from stable isotope data (Leier et al., 2013), We suggest that buckling instabilities in a subducting plate offer a plausible explanation in the variability and timing of the Nazca plate deformation during the last $\sim 20 \mathrm{Ma}$ as well as the present-day deep seismicity distribution (supplementary Fig.7b). We find that shortening rate pulses occur at the end of each buckling cycle when slab steepening inhibits trench retreat (Fig. 7cd), and that these pulses reproduce similar signals to what is seen in the geological data. Additionally, in the last 2 Ma the geological data shows a decrease in the shortening rate, which is also predicted by our model through underthrusting. At later stages, the trench retreat resumes and underthrusting loses its efficiency, which could indicate the beginning of a new buckling cycle.

Previous studies have suggested that the lower mantle viscosity and the dip, age,

343 thickness and strength of the oceanic plate may affect the buckling periodicity and timing of 344 slab stagnation in the transition zone (Ribe et al., 2007; Lee \& King, 2011; Quinteros et al., 
345 2010; Quinteros \& Sobolev, 2013; Marquardt \& Miyagi, 2015; Cerpa et al., 2017; Briaud et

346 al., 2020). Analyzing the variety of interchangeable parameters affecting the buckling process 347 exceeds the scope of this study.

348 Previous seismic tomography studies indicate two large negative seismic anomalies near 349 the transition zone ( at depths of $600 \mathrm{~km}$ and $900 \mathrm{~km}$ ) that are attributed to slab accumulations 350 (Widiyantoro, 1997; Liu, 2003; Chen et al., 2019). The deeper accumulation may relate to a 351 slab anchoring (Faccenna et al., 2017, Supplementary Fig.7), suggesting that previous 352 accumulation cycles could have occurred before and have "avalanched" in the lower mantle 353 (Briaud et al., 2020; Hu \& Gurnis, 2020), wherein they may have become detached from the 354 shallower slab. Indeed, over the last 200 Ma quick alternations between compressive and 355 extensive phases (e.g., the compressive peruvian phase or extensive Salta rift between $\sim 120$ Ma and 60 Ma; Faccenna et al., 2017) may indicate that slab buckling events have happened earlier in the subduction history. However, because of the absence of an efficient weakening mechanism to trigger delamination and too thin crust to facilitate eclogitization, the orogen experienced no significant deformation. Potentially, we suggest that these avalanche events may have repeated at least 3 times over the last $\sim 90 \mathrm{Ma}$, as suggested by the 3 cycles of convergence rate recognized in Martinod et al., (2010).

\section{Conclusion.}

In this study, we propose that dynamic slab mechanics result in cycles of slab buckling that can explain the the timing and amplitude of the tectonic shortening pulses seen in in the Central Andes since the Late Eocene. Using geodynamic numerical models, we infer that the primary cause of these pulses that contributed to the growth of the Central Andes is the evolving geometry of the subducting Nazca plate. Inparticular, the steepening of the slab near the transition zone slows down the trench retreat and subsequent shortening of the advancing South American plate. This steepening first occurs after the end of the flat slab episode at 25 Ma. By eroding the lower part of the mantle lithosphere, this episode predisposes the 
371 margin for the next deformation phases by decreasing its strength. Later, slab steepening 372 occurs following the buckling of the slab in the mantle transition zone. This new buckling373 steepening mechanism sheds light on the causes of the rapid pulsatile growth of the Central 374 Andes during the last $\sim 20 \mathrm{Ma}$, and the model evolution is consistent with geological data 375 (Oncken et al., 2012) and with the timing of uplift (Garzione et al., 2017) of the Altiplano 376 plateau. 


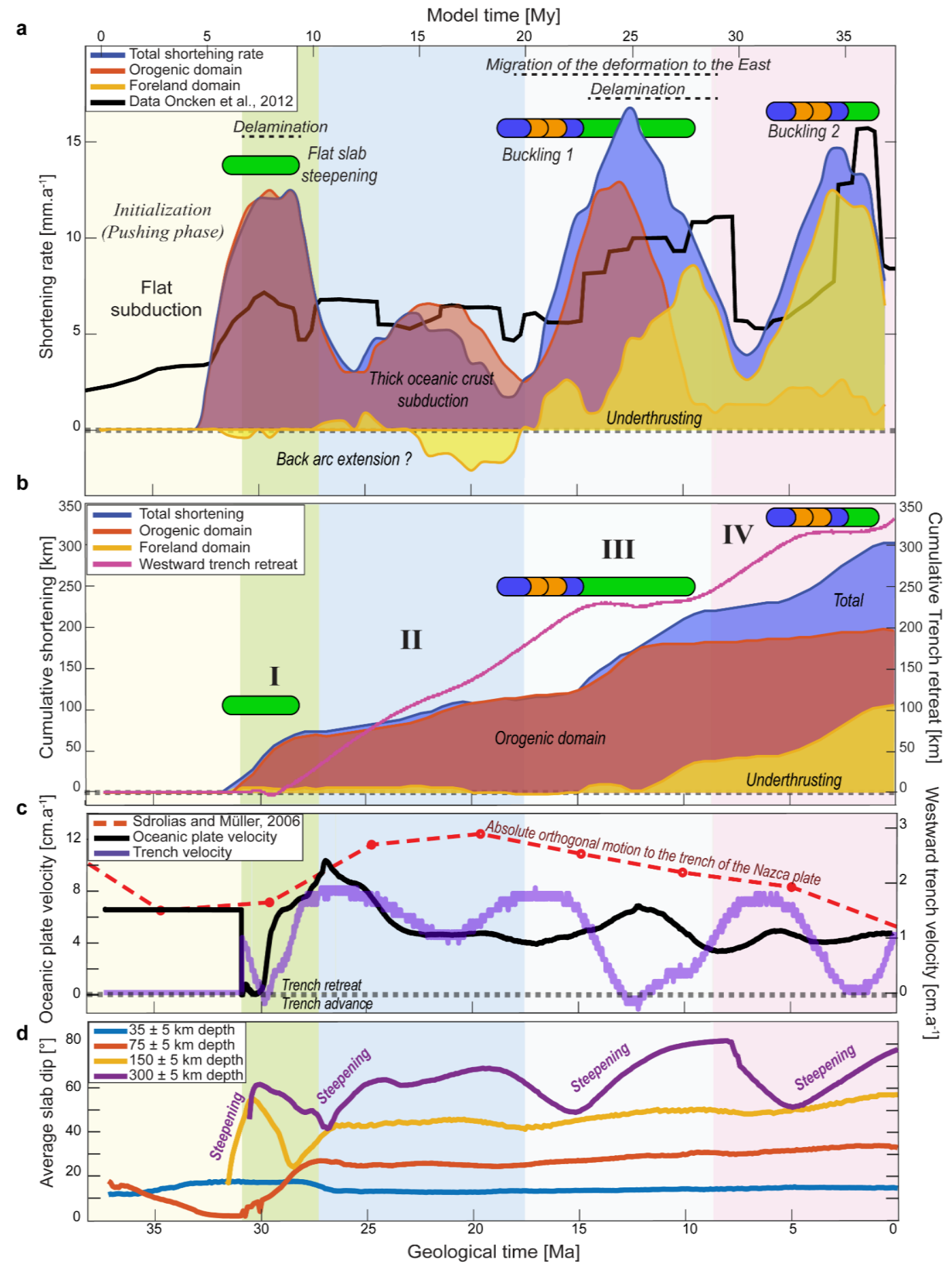

Fig. 7 Summary exposing the relation between continental plate deformation (a and $\mathbf{b}$ ) and oceanic plate dynamics (b and $\mathbf{c}$ ) for the reference model. Background colors indicate the shortening phases. Colored pills indicate the slab evolution stage as in figure 6. a Smoothed shortening rate for the orogenic and foreland domain (see data acquisition and processing for details). b Cumulative shortening for the orogenic and foreland domain and cumulative trench 383 retreat. Numbers indicate the shortening phases. c Velocity of the oceanic plate (black line) and trench migration rate (purple line). d Average slab dip for different depth intervals. 


\section{Methods}

386 Governing equations We used the geodynamic finite element code ASPECT (Advanced

387 Solver for Problems in Earth's ConvecTion, version 2.3.0-pre, Bangerth et al., 2021; 388 Kronbichler et al., 2012; Heister et al., 2017; Rose et al., 2017) to setup a 2D subduction model 389 (e.g., Faccenna et al., 2017). The model solves three conservation equations for the 390 momentum (1), mass (2) and energy (3) and the advection and reaction equations for the different compositional fields. The energy equation includes the radiogenic heating, shear heating and adiabatic heating.

$$
-\nabla \cdot(2 \eta \varepsilon \dot{\varepsilon})+\nabla p=\rho g,
$$

$$
\nabla \cdot \boldsymbol{u}=0
$$

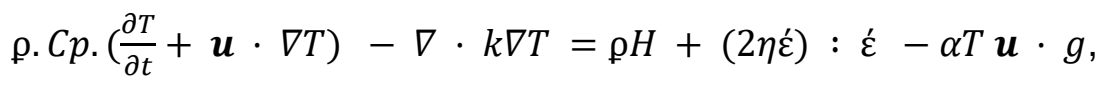

$$
\frac{\partial c i}{\partial t}+\boldsymbol{u} \cdot \nabla c i=q i
$$

397 with the deviatoric strain rate tensor $\dot{\varepsilon}=\frac{1}{2} \cdot\left(\nabla \boldsymbol{u}+(\nabla \boldsymbol{u})^{T}, \boldsymbol{u}=u(\vec{x}, t)\right.$ the velocity field, $p=$ $398 p(\vec{x}, t)$ is the pressure, $T=T(\vec{x}, t)$ is the temperature, $\mathrm{Cp}$ is the heat capacity, $\rho$ is the 399 density, $\rho$ is the reference density, $\mathrm{k}$ is the conductivity, $\alpha$ is the thermal expansivity, $\mathrm{H}$ is the 400 radiogenic heat production, $\eta$ is the viscosity, $t$ is the time, $c i$ is the composition and qi is the 401 reaction rate.

402 Although the model is incompressible, we wanted to simulate realistic phase 403 transformations that require a temperature and pressure dependent compressible density 404 formulation, therefore, we used the equation of state of Murnaghan (5) (Murnaghan, 1944). 405 Previous studies have shown compressibility to have a small effect on mass conservation for 406 subduction models, suggesting that it can likely be neglected (Fraters, 2014).

$$
\rho f=\operatorname{\rho refi}\left(1 .+\left(P-\left(\frac{\alpha i}{\beta i}\right) \cdot(T-\operatorname{Tr} e f)\right) \cdot k i \cdot \beta i\right)^{1 / k i},
$$


408 Where $\rho f$ is the final density and $\rho r e f i$ is the reference density for each composition at 409 surface pressures and a surface temperature of $293 \mathrm{~K}$ (Tref). $\alpha i$ is the thermal expansivity, $\beta i$ 410 is the isothermal compressibility, and $k i$ is the isothermal bulk modulus pressure derivatives.

411 We used a visco-platic material model that allows for viscous (ductile) and plastic (Brittle) 412 deformation (Glerum et al., 2018). The viscous regime is handled using a harmonic average 413 of contribution dislocation and diffusion creep (6), whereas the plastic regime uses the 414 Drucker-Prager criterion. The dominant mechanism (viscous vs. plastic) is determined through 415 the yield stress.

$$
\eta_{\text {diff } \mid \text { disl }}=0.5 A_{\text {diff } \mid \text { disl }}^{(-1 / \mathrm{n})} d^{m} \dot{\varepsilon}_{\mathrm{e}}^{(1 .-\mathrm{n}) / \mathrm{n}} \exp \left(\frac{Q_{\text {diff } \mid \mathrm{disl}}+P . V_{\text {diff } \mid \mathrm{disl}}}{n R T}\right),
$$

417 A is the prefactor rescaled from uniaxial experiment, $n$ is the stress exponent, $d$ and $m$ are the grain size and grain size exponent, $\dot{\varepsilon}_{e}$ is the square root of deviatoric strain rate, $Q$ is the

419 Energy of activation, $\mathrm{V}$ is the volume of activation, $\mathrm{P}$ the pressure, $\mathrm{R}$ the gas constant and $\mathrm{T}$ 420 the temperature. Dislocation is independent of the grain size so $\mathrm{d}^{\wedge} \mathrm{m}$ is removed from the equation. For a $2 \mathrm{~d}$ model the yield stress $\sigma y$ is equivalent to the mohr Coulomb surface criterion (7).

$$
\sigma y=C \cdot \cos (F)+P \cdot \sin (F)
$$

Where $\mathrm{C}$ is the Cohesion, $\mathrm{P}$ the pressure and $\mathrm{F}$ the internal friction angle in radian. We also 426 included linear plastic strain softening of the friction and cohesion that depends on the strain accumulation over time (supplementary, Table 1).

The effective viscosity is then calculated by

$$
\eta=\frac{\sigma y}{2 \dot{\varepsilon}},
$$

Model set up. We split the box into 2 sub-boxes; a $96 \mathrm{~km}$ thick (in depth) box that represents the lithosphere, and an $804 \mathrm{~km}$ thick box that represents the asthenosphere. This gives us more flexibility by allowing us to set independent boundary conditions for each box 
on the east and west boundaries. For example, we prescribe the lithosphere velocities

434 whereas the asthenosphere uses the initial lithostatic pressure to simulate an open boundary.

435 The final box is $2592 \times 900 \mathrm{~km}$ (calculated to have square cells, and an aspect ratio of $\sim 1: 3$ or $\sim 1: 6$ if we only consider the upper mantle; Gerya, 2019). The adaptive mesh refines based on the compositional fields and the strain rate. Additionally, the asthenospheric mantle resolution is resolved to a fixed resolution of $32 \mathrm{~km}$ and the slab's mantle lithosphere at $4 \mathrm{~km}$.

439 The topography is uplifted and advected using the ASPECT-FaStscape coupling (Braun \& 440 Willet, 2013; Bovy, 2021; Neuharth et al., 2021a; 2021b). This method allows us to track and 441 store the topography for analysis. However, other than a very small $\left(\sim 1 \mathrm{e}-6 \mathrm{~m}^{2} / \mathrm{yr}\right)$ diffusion coefficient that does not affect the results presented here, we exclude surface processes.

443 Subduction interface. Our models use a visco-plastic subduction interface based on the weakest quartzite rheological flow law from Ranalli (1997). This rheology was shown to be efficient in modeling a quartz-dominated "melange" at the interface (Sobolev et al., 2006; Muldashev \& Sobolev, 2020).

Rheology. (Supplementary Table. 1) The oceanic plate is composed of an $8 \mathrm{~km}$ oceanic crust $\left(3000 \mathrm{~kg} / \mathrm{m}^{3}\right)$ divided into $5 \mathrm{~km}$ of weak wet quartzite (Ranalli, 1997) and $3 \mathrm{~km}$ of mafic diabase (Mackwell et al., 1998). The oceanic mantle consists of $73 \mathrm{~km}$ of dry olivine (Hirth \& Kohlstedt, 2004), and is compositionally lighter than the asthenosphere ( $\rho$ Asthenosphere - 20 $\mathrm{kg} / \mathrm{m}^{3}$ ). The lithosphere is given an initial dip of $\sim 15^{\circ}$ to facilitate the initial flat slab stage (Van

452 Hunen et al., 2004; Huangfu et al., 2016; Liu \& Currie, 2016; Dai et al., 2020). A 12 km thick 453 "ridge" $\left(2800 \mathrm{~kg} / \mathrm{m}^{3}\right)$ of weak quartz (Ranalli, 1997) is placed along the dipping subduction 454 interface to aid in subduction initialization.

455 The geometry and length of the continent are based on a structural reconstruction and a 456 volume conservation at $30 \mathrm{Ma}$ (Armijo et al., 2015; Sobolev et al., 2006) that have been 457 calibrated to have an $\sim 850 \mathrm{~km}$ long continent when the model is restarted after the 458 initialization phase. In the central domain, the upper crust $\left(2800 \mathrm{~kg} / \mathrm{m}^{3}\right)$ is a $33 \mathrm{~km}$ thick layer 
of wet quartzite (Gleason \& Tullis, 1995) and the lower crust $\left(3000 \mathrm{~kg} / \mathrm{m}^{3}\right)$ is a $12 \mathrm{~km}$ thick

460 layer of diabase (Mackwell et al., 1998). The continental mantle $\left(3280 \mathrm{~kg} / \mathrm{m}^{3}\right)$ is wet olivine 461 (Hirth \& Kohlstedt, 2004) and $45 \mathrm{~km}$ thick. In the cold forearc the continental mantle thickens 462 to $65 \mathrm{~km}$. In the foreland, sediments $\left(2670 \mathrm{~kg} / \mathrm{m}^{3}\right)$ are $5 \mathrm{~km}$ thick (Gleason \& Tullis, 1995). 463 The upper crust and the lower crust are 12 and $10 \mathrm{~km}$ thick, respectively. The depleted 464 Brazilian cratonic shield $\left(3240 \mathrm{~kg} / \mathrm{m}^{3}\right)$ is considered dry olivine (Hirth \& Kohlstedt, 2004) and 465 extends to a depth of $130 \mathrm{~km}$. The foreland is thicker than the central domain and therefore 466 colder (Sobolev et al., 2006; Ibarra \& Prezzi, 2019; Ibarra et al., 2019).

Asthenospheric densities are recalculated so that the final density after considering the 468 pressure and temperature matches the PREM model (Dziewonski \& Anderson, 1981). To 469 simulate the rheology of the hydrated mantle wedge in the upper mantle, we use wet olivine laws for dislocation and diffusion (Hirth \& Kohlstedt, 2004) $\left(3300 \mathrm{~kg} / \mathrm{m}^{3}\right)$. We prescribed constant viscosity for the transition zone $(410-520 \mathrm{~km} \sim 6.75 \mathrm{e} 20$ Pa.s and 520-660 km $\sim 1.05 \mathrm{e} 21$ Pa.s) and the lower mantle ( 7.5e21 Pa.s) based on the Steinberger \& Calderwood (2006) viscosity profile.

The main phase transitions were consider for the mantle are the Olivine-Wadsleyite at 410 475 $\mathrm{km}$ depth (Clapeyron slope, $\lambda$, of $2 \mathrm{MPa} / \mathrm{K})$, Wadsleyite-Ringwoodite at $520 \mathrm{~km}(\lambda=3.5 \mathrm{MPa} / \mathrm{K})$ and Post-spinel at $660 \mathrm{~km}(\lambda=-0.5 \mathrm{MPa} / \mathrm{K}$; Quinteros \& Sobolev, 2013). Gabbro-eclogite transition $\left(+450 \mathrm{~kg} / \mathrm{m}^{3}\right)$ is completed at pressures of $\sim 1.9 \mathrm{GPa}\left(\sim 60 \mathrm{~km}\right.$ depth) and $800^{\circ} \mathrm{C}$ for 478 the oceanic crust and $\sim 1.2 \mathrm{GPa}\left(\sim 40 \mathrm{~km}\right.$ depth) and $700^{\circ} \mathrm{C}$ for the lower crust (Babeyko et al., 479 2006; Sobolev \& Babeyko, 1994; Sobolev et al., 2006). Coesite-Stishovite phase transition 480 also takes place at a pressure of $~ 9$ GPa ( 270 km depth) (Faccenda \& Dal Zilio, 2017).

481 Initialization. Our goal is to investigate the temporal variation of the overriding plate 482 shortening starting from flat subduction. For that reason, we do not allow plastic strain to 483 accumulate during initialization. To initiate the flat slab, we prescribed a $\sim 400 \mathrm{~km}$ long plateau 484 domain that corresponds to the dipping part of the slab, in which we split the $73 \mathrm{~km}$ oceanic 
lithosphere into $43.8 \mathrm{~km}$ of depleted "Harzburgite" $\left(3233 \mathrm{~kg} / \mathrm{m}^{3}\right)$ and $51.1 \mathrm{~km}$ of "Lherzolite"

486 (3300 kg/m³; Arredondo \& Billen, 2017). This gives an average density of $\sim 3260 \mathrm{~kg} / \mathrm{m}^{3}$.

487 Additionally, during initialization there is no eclogitization in the "ridge".

488 We pushed the oceanic plate at $7 \mathrm{~cm} / \mathrm{yr}$, similar to the absolute orthogonal velocity of the 489 Nazca plate at $\sim 35 \mathrm{Ma}$, and we pushed the overriding plate at $2 \mathrm{~cm} / \mathrm{yr}$ (Sdrolias \& Müller, 490 2006). The left asthenosphere boundary is open whereas the right and the bottom are set to 491 free slip to avoid any "artificial mantle wind" that could arise from pressure perturbations. 492 During initialization, we use a fully viscous interface to achieve flat subduction without any significant deformation inthe overriding plate. We set the minimum viscosity to 1 e20 Pa.s for the first $1 \mathrm{My}$ in order to dampen the high velocities that could arise from isostatic rebound. After 1 My the minimum viscosity is switched to $1 \mathrm{e} 19$ Pa.s. The interface viscosity is set to 5e19 Pa.s as this gives the minimum coupling strength required for flat subduction. As the slab warms, the oceanic crust eclogitized and its tip steepens, the initialization stops when the slab tip reaches $300 \mathrm{~km}$ depth.

When the model is retarted after the flat subduction phase, the interface is set to include 500 visco-plastic deformation. The "ridge" density is set to $3000 \mathrm{~kg} / \mathrm{m}^{3}$ to prevent relamination and eclogitization of the continent when the temperatures overcome a blocking temperature of $700^{\circ} \mathrm{C}$ (Sobolev \& Babeyko, 1994; Babeyko et al., 2006). The minimum viscosity is set to 2.5e18 Pa.s. The "Harzburgite" and "Lherzolite" density are changed to represent normal oceanic mantle $\left(3280 \mathrm{~kg} / \mathrm{m}^{3}\right)$, and the left boundary is fully open.

Data acquisition and processing. Shortening for the main orogenic domain is aquired by tracking the extremities of the upper crust at the surface, from the trench to the sediments in the foreland. Underthrusting is obtained by tracking the difference between the eastern extremity of the orogenic domain and the western extremity of the craton. Next, to find the shortening rate we divided the total shortening by the timestep. To be comparable to the

510 geological shortening rate that has a temporal resolution between 1 to 5 My (Oncken et al., 
511 2006) we smoothed the solution using a 5 My moving average filter. The position of the trench

512 corresponds to the lowest point of the topography. We determine the position of the trench

513 using the minimum topography in the model, and then determine the velocity by dividing the

514 change of position by the time step. The noise observed in the solution (e.g Fig.7) is caused

515 by the difference of resolution at the trench; we applied a moving average filter of 200 ka to

516 reduce it without losing the main signal. Note that we refer to the plastic strain rate and the

517 viscous strain rate whereas they are the second invariant of the square root of the deviatoric

518 strain rate in the plastic and viscous domain, respectively. The plastic strain refers to the

519 integrated plastic strain rate over time and allows us to identify places that were already

520 deformed and weakened.

521 Model limitations. The main limitation of our model is its two-dimensionality. The use of

522 2D modeling is appropriate for the Central Andes, where toroidal flow affecting the edges of

523 the Nazca plate can be neglected. However, Hindle et al., (2005) estimated latitudinal crustal

524 flow to contribute between $\sim 10 \%$ to $30 \%$ of the present day crustal thickness of the Central

525 Andes. In our models the crustal thickening is mainly caused by intraplate shortening. As a

526 result, the lithospheric thickness of the orogen in our models is lower than the actual crustal

527 thickness of the Central Andes. For example, in model S1 the final orogenic lithosphere

528 thickness is $\sim 57 \mathrm{~km}$, whereas it should increase to $\sim 62-74 \mathrm{~km}$ taking into account the

529 latitudinal component.

$530 \quad$ In model S1 the final dip of the slab is steeper than in seismic tomography (supplementary

531 Fig. 7a), which plausibly indicates the occurrence of deep mantle flow that is not considered

532 in our model, or that trench retreat is underestimated (supplementary Fig. 7b). Buckling of the

533 slab could provide an explanation for the deep seismicity distribution (supplementary Fig. 7b).

534 Alternatively, Model S2a (interplate friction 0.015) indicates that a slight change of effective

535 low friction at the interface can result in a shallower slab due to efficient trench retreat

536 (supplementary Fig. 2). 
We find that with an interplate effective friction of 0.05 (supplementary Fig.4), the

538 maximum amplitude of the modeled subduction velocity is lower than the absolute normal

539 velocity of the Nazca plate $(\sim 12.5 \mathrm{~cm} / \mathrm{yr}$ at $\sim 20 \mathrm{Ma}$, Sdrolias \& Müller, 2006). This suggests

540 that because we neglect $3 \mathrm{D}$ effects, we may overestimate the average interface friction

541 resulting in reduced velocities relative to the paleomagnetic data.

542

\section{Acknowledgement}

544 This research was funded by the DeutscheForschungsgemeinschaft (DFG) and the

545 Federal State of Brandenburg under the guidance of the International Research Training

546 Group IGK2018 "SuRfAce processes, TEctonics and Georesources: The Andean foreland

547 basin of Argentina" (STRATEGy DFG 373/34-1). The authors thank the Computational

548 Infrastructure for Geodynamics (geodynamics.org), which is funded by the National Science

549 Foundation under award EAR-0949446 and EAR-1550901, for supporting the development of

550 ASPECT. The computations of this work were supported by the North-German

551 Supercomputing Alliance (HLRN). We also thank Onno Oncken and Claudio Faccenna and

552 Constanza Rodriguez Piceda for their constructive comments.

553 Data availability

554 The input files to reproduce the results of this paper are available at 555 https://doi.org/10.5880/GFZ.2.5.2022.001. Figures in the paper were made with Paraview and 556 Illustrator. The color scales were taken from Crameri (10.5281/zenodo.5501399).

\section{Code availability}

558 The ASPECT code is open source and hosted on github

559 https://github.com/geodynamics/aspect. The models where run with the ASPECT version

560 2.3.0-pre built with the 9.2.0 version of Deal.ii. We have modified the main ASPECT branch to 561 implement new custom plugins necessary for the model set up and the prostprocessing 
562 accessible from https://github.com/Minerallo/aspect/tree/Paper slab buckling Andes. The

563 input parameters files and initial temperature and composition are also available from

$564 \quad$ https://doi.org/10.5880/GFZ.2.5.2022.001.

\section{Author contributions}

566 M.P is the main investigator of this work, he built and ran the simulation, analyzed the data 567 and led the writing of the manuscript. S.V.S contributed to the design of the model as well as 568 the data interpretation and discussion. S.L contributed to the writing of the manuscript. D.N 569 contributed to the model building and design, and developed the coupling between ASPECT 570 and FASTSCAPE that handle the mesh deformation.

\section{Appendix or supplementary information}

572 Supplementary information

573 Movie S1, S1b, S2a, S2b, S2c, S3, S4

\section{References}

Allmendinger, R. W., \& Gubbels, T. (1996). Pure and simple shear plateau uplift, Altiplano-Puna, Argentina and Bolivia. Tectonophysics, 259(1-3 SPEC. ISS.), 1-13. https://doi.org/10.1016/0040-1951(96)00024-8

Allmendinger, R. W., Jordan, T. E., Kay, S. M., \& Isacks, B. L. (1997). The evolution of the Altiplano-Puna plateau of the Central Andes. Annual Review of Earth and Planetary Sciences, 25, 139-174. https://doi.org/10.1146/ANNUREV.EARTH.25.1.139

Armijo, R., Lacassin, R., Coudurier-Curveur, A., \& Carrizo, D. (2015). Coupled tectonic evolution of Andean orogeny and global climate. Earth-Science Reviews, 143, $1-35$.

Arredondo, K. M., \& Billen, M. I. (2016). The effects of phase transitions and compositional layering in two-dimensional kinematic models of subduction. Journal of Geodynamics, 100, 159-174. https://doi.org/10.1016/J.JOG.2016.05.009

Arredondo, K. M., \& Billen, M. I. (2017). Coupled effects of phase transitions and rheology in 2-D dynamical models of subduction. Journal of Geophysical Research: Solid Earth, 122(7), 5813-5830. https://doi.org/10.1002/2017JB014374

Babeyko, A. Y., \& Sobolev, S. V. (2005). Quantifying different modes of the late Cenozoic shortening in the central Andes. Geology, 33(8), 621-624. https://doi.org/10.1130/G21126.1

Babeyko, A. Y., Sobolev, S. V., Trumbull, R. B., Oncken, O., \& Lavier, L. L. (2002). Numerical models of crustal scale convection and partial melting beneath the Altiplano-Puna plateau. Earth and Planetary Science Letters, 199(3-4), 373-388. https://doi.org/10.1016/S0012-821X(02)00597-6 Babeyko, A. Y., Sobolev, S. V., Vietor, T., Oncken, O., \& Trumbull, R. B. (2006). Numerical Study of Weakening Processes in the Central Andean Back-Arc. The Andes - Active Subduction Orogeny, 495-512. https://doi.org/10.1007/978-3-540-48684-8

Bangerth, W., Dannberg, J., Fraters, M., Gassmoeller, R., Glerum, A., Heister, T., \& Naliboff, J. (2021). ASPECT v2.3.0. Zenodo. https://doi.org/10.5281/zenodo.5131909

Barazangi, M., \& Isacks, B. L. (1976). Spatial distribution of earthquakes and subduction of the Nazca plate beneath South America. Geology, 4(11), 686-692. https://doi.org/10.1130/0091-7613(1976)4<686:SDOEAS>2.0.CO;2

Beck, S. L., \& Zandt, G. (2002). The nature of orogenic crust in the central Andes. Journal of Geophysical Research: Solid Earth, 107(B10), ESE 7-1-ESE 7-16. https://doi.org/10.1029/2000JB000124 
Beck, S. L., Zandt, G., Ward, K. M., \& Scire, A. (2015). Multiple styles and scales of lithospheric foundering beneath the Puna Plateau, central Andes. https://doi.org/10.1130/2015.1212(03)

Becker, T. W., Schaeffer, A. J., Lebedev, S., \& Conrad, C. P. (2015). Toward a generalized plate motion reference frame. Geophysical Research Letters, 42(9), 3188-

Bello-González, J. P., Contreras-Reyes, E., \& Arriagada, C. (2018). Predicted path for hotspot tracks off South America since Paleocene times: Tectonic implications of ridge-trench collision along the Andean margin. Gondwana Research, 64, 216-234. https://doi.org/10.1016/j.gr.2018.07.008

Boschman, L. M. (2021). Andean mountain building since the Late Cretaceous: A paleoelevation reconstruction. Earth-Science Reviews, 103640.

Bovy, B. (2021). fastscape-lem/fastscape: Release v0.1.0beta3. Zenodo. https://doi.org/10.5281/zenodo. 4435110

Braun, J., \& Willett, S. D. (2013). A very efficient O (n), implicit and parallel method to solve the stream power equation governing fluvial incision and landscape evolution. Geomorphology, 180, 170-179.

Briaud, A., Agrusta, R., Faccenna, C., Funiciello, F., \& van Hunen, J. (2020). Topographic Fingerprint of Deep Mantle Subduction. Journal of Geophysical Research: Solid Earth, 125(1), e2019JB017962. https://doi.org/10.1029/2019JB017962

Brizzi, S., van Zelst, I., Funiciello, F., Corbi, F., \& van Dinther, Y. (2020). How Sediment Thickness Influences Subduction Dynamics and Seismicity. Journal of Geophysical Research: Solid Earth, 125(8), e2019JB018964. https://doi.org/10.1029/2019JB018964

Cerpa, N. G., Hassani, R., Gerbault, M., \& Prévost, J. H. (2014). A fictitious domain method for lithosphere-asthenosphere interaction: Application to periodic slab folding in the upper mantle. Geochemistry, Geophysics, Geosystems, 15(5), 1852-1877.

Chen, Y. W., Wu, J., \& Suppe, J. (2019). Southward propagation of Nazca subduction along the Andes. Nature, 565(7740), 441-447. https://doi.org/10.1038/S41586018-0860-1

Cosentino*, N. J., Aron, F., Crempien, J. G. F., \& Jordan, T. E. (2018). Role of subducted sediments in plate interface dynamics as constrained by Andean forearc (paleo)topography. https://doi.org/10.1130/2018.2540(03)

Dai, L., Wang, L., Lou, D., Li, Z.-H., Dong, H., Ma, F., Li, F., Li, S., \& Yu, S. (2020). Slab Rollback Versus Delamination: Contrasting Fates of Flat-Slab Subduction and Implications for South China Evolution in the Mesozoic. Journal of Geophysical Research: Solid Earth, 125(4), e2019JB019164. https://doi.org/10.1029/2019JB019164

Decelles, P. G., Ducea, M. N., Kapp, P., \& Zandt, G. (2009). Cyclicity in Cordilleran orogenic systems. Nature Geoscience, 2(4), $251-257$. https://doi.org/10.1038/NGEO469

Dziewonski, A. M., \& Anderson, D. L. (1981). Preliminary reference Earth model. Physics of the Earth and Planetary Interiors, 25(4), $297-356$. https://doi.org/10.1016/0031-9201(81)90046-7

Faccenda, M., \& Dal Zilio, L. (2017). The role of solid-solid phase transitions in mantle convection. Lithos, 268-271, 198-224. https://doi.org/10.1016/.j.lithos.2016.11.007

Faccenna, C., Oncken, O., Holt, A. F., \& Becker, T. W. (2017). Initiation of the Andean orogeny by lower mantle subduction. Earth and Planetary Science Letters, 463, 189-201. https://doi.org/10.1016/J.EPSL.2017.01.041

https://doi.org/10.1016/j.jsames.2017.12.012

Fraters, M. (2014). Thermo-mechanically coupled subduction modelling with ASPECT. August. https://dspace.library.uu.nl/handle/1874/297347

Funiciello, F., Faccenna, C., Heuret, A., Lallemand, S., Di Giuseppe, E., \& Becker, T. W. (2008). Trench migration, net rotation and slab-mantle coupling. Earth and Planetary Science Letters, 271(1-4), 233-240. https://doi.org/10.1016/J.EPSL.2008.04.006

Gao, Y., Tilmann, F., van Herwaarden, D. P., Thrastarson, S., Fichtner, A., Heit, B., ... \& Schurr, B. D. (2021). Full Waveform Inversion beneath the Central Andes: Insight into the dehydration of the Nazca slab and delamination of the back-arc lithosphere. Earth and Space Science Open Archive ESSOAr.

Garzione, C. N., Molnar, P., Libarkin, J. C., \& MacFadden, B. J. (2006). Rapid late Miocene rise of the Bolivian Altiplano: Evidence for removal of mantle lithosphere. Earth and Planetary Science Letters, 241(3-4), 543-556. https://doi.org/10.1016/J.EPSL.2005.11.026

Garzione, C. N., Hoke, G. D., Libarkin, J. C., Withers, S., MacFadden, B., Eiler, J., Ghosh, P., \& Mulch, A. (2008). Rise of the Andes. Science, 320(5881), $1304-1307$. https://doi.org/10.1126/SCIENCE.1148615

Garzione, C. N., McQuarrie, N., Perez, N. D., Ehlers, T. A., Beck, S. L., Kar, N., Eichelberger, N., Chapman, A. D., Ward, K. M., Ducea, M. N., Lease, R. O., Poulsen, C. J., Wagner, L. S., Saylor, J. E., Zandt, G., \& Horton, B. K. (2017). Tectonic Evolution of the Central Andean Plateau and Implications for the Growth of Plateaus. Annual Review of Earth and Planetary Sciences, 45(1), 529-559. https://doi.org/10.1146/annurev-earth-063016-020612

Gerbault, M., Cembrano, Mpodozis, J., Farias, C., \& Pardo M, M. (2009). Continental Margin Deformation along the Andean Subduction zone: Thermomechanical Models. Physics of the Earth and Planetary Interiors, 177(3-4), 180. https://doi.org/10.1016/j.pepi.2009.09.001 Gerya, T. (2019). Introduction to Numerical Geodynamic Modelling (2nd ed.). Cambridge University Press. https://doi.org/10.1017/9781316534243 Gleason, G. C., \& Tullis, J. (1995). A flow law for dislocation creep of quartz aggregates determined with the molten salt cell. Tectonophysics, 247(1-4), 1-23. https://doi.org/10.1016/0040-1951(95)00011-B 
Glerum, A., Thieulot, C., Fraters, M., Blom, C., \& Spakman, W. (2018). Nonlinear viscoplasticity in ASPECT: benchmarking and applications to subduction. Solid Earth, 9(2), 267-294

Heister, T., Dannberg, J., Gassmöller, R., \& Bangerth, W. (2017). High accuracy mantle convection simulation through modern numerical methods—II: Realistic models and problems. Geophysical Journal International, 210(2), 833-851. https://doi.org/10.1093/GJI/GGX195

Heuret, A., Conrad, C. P., Funiciello, F., Lallemand, S., \& Sandri, L. (2012). Relation between subduction megathrust earthquakes, trench sediment thickness and upper plate strain. Geophysical Research Letters, 39, L05304. https://doi.org/10.1029/2011GL050712

Hindle, D., Kley, J., Oncken, O., \& Sobolev, S. (2005). Crustal balance and crustal flux from shortening estimates in the Central Andes. Earth and Planetary Science Letters, 230(1-2), 113-124. https://doi.org/10.1016/J.EPSL.2004.11.004

Hirth, G., \& Kohlstedt, D. (2004). Rheology of the upper mantle and the mantle wedge: A view from the experimentalists. Geophysical Monograph Series, 138, 83-105. https://doi.org/10.1029/138GM06

Holt, A. F., Becker, T. W., \& Buffett, B. A. (2015). Trench migration and overriding plate stress in dynamic subduction models. Geophysical Journal International, 201(1), 172-192. https://doi.org/10.1093/GJI/GGV011

Horton, B. (2018). Tectonic regimes of the Central and Southern Andes: Responses to variations in plate coupling during subduction. Tectonics, 37(2), 402-429. https://doi.org/10.1002/2017tc004624

Hu, J., \& Gurnis, M. (2020). Subduction Duration and Slab Dip. Geochemistry, Geophysics, Geosystems, 21(4), e2019GC008862. https://doi.org/10.1029/2019GC008862

Huangfu, P., Wang, Y., Cawood, P. A., Li, Z. H., Fan, W., \& Gerya, T. V. (2016). Thermo-mechanical controls of flat subduction: Insights from numerical modeling Gondwana Research, 40(December), 170-183. https://doi.org/10.1016/j.gr.2016.08.012

Husson, L., Conrad, C. P., \& Faccenna, C. (2012). Plate motions, Andean orogeny, and volcanism above the South Atlantic convection cell. Earth and Planetary Science Letters, 317-318, 126-135. https://doi.org/10.1016/j.epsl.2011.11.040

Ibarra, F., Liu, S., Meeßen, C., Prezzi, C. B., Bott, J., Scheck-Wenderoth, M., Sobolev, S., \& Strecker, M. R. (2019). 3D data-derived lithospheric structure of the Central Andes and its implications for deformation: Insights from gravity and geodynamic modelling. Tectonophysics, 766(February), 453-468. https://doi.org/10.1016/.tecto.2019.06.025

Ibarra, F., \& Prezzi, C. B. (2019). The thermo-mechanical state of the andes in the altiplano-puna region: Insights from curie isotherm and effective elastic thickness determination. Revista de La Asociacion Geologica Argentina, 76(4), 352-362.

Isacks, B. L. (1988). Uplift of the central Andean Plateau and bending of the Bolivian Orocline. Journal of Geophysical Research, 93(B4), 3211-3231. https://doi.org/10.1029/JB093IB04P03211

Kay, R. W., \& Mahlburg Kay, S. (1993). Delamination and delamination magmatism. Tectonophysics, 219(1-3), 177-189. https://doi.org/10.1016/0040-1951(93)90295U

Kley, J., Monaldi, C. R., \& Salfity, J. A. (1999). Along-strike segmentation of the Andean foreland: Causes and consequences. Tectonophysics, 301(1-2), 75-94. https://doi.org/10.1016/S0040-1951(98)90223-2

Kronbichler, M., Heister, T., \& Bangerth, W. (2012). High accuracy mantle convection simulation through modern numerical methods. Geophysical Journal International, 191(1), 12-29. https://doi.org/10.1111/J.1365-246X.2012.05609.X

Lallemand, S., Heuret, A., \& Boutelier, D. (2005). On the relationships between slab dip, back-arc stress, upper plate absolute motion, and crustal nature in subduction zones. Geochemistry, Geophysics, Geosystems, 6(9). https://doi.org/10.1029/2005GC000917

Lallemand, S., Heuret, A., Faccenna, C., \& Funiciello, F. (2008). Subduction dynamics as revealed by trench migration. Tectonics, 27(3). https://doi.org/10.1029/2007TC002212

Lamb, S., \& Davis, P. (2003). Cenozoic climate change as a possible cause for the rise of the Andes. Nature, 425(6960), 792-797. https://doi.org/10.1038/NATURE02049

Lee, C., \& King, S. D. (2011). Dynamic buckling of subducting slabs reconciles geological and geophysical observations. Earth and Planetary Science Letters, 312(34), 360-370.

Leier, A., McQuarrie, N., Garzione, C., \& Eiler, J. (2013). Stable isotope evidence for multiple pulses of rapid surface uplift in the Central Andes, Bolivia. Earth and Planetary Science Letters, 371-372, 49-58. https://doi.org/10.1016/j.epsl.2013.04.025

Liu, K. H., Gao, S. S., Silver, P. G., \& Zhang, Y. (2003). Mantle layering across central South America. Journal of Geophysical Research: Solid Earth, 108(B11).

Liu, S., \& Currie, C. A. (2016). Farallon plate dynamics prior to the Laramide orogeny: Numerical models of flat subduction. Tectonophysics, $666,33-47$.

Liu, S., Sobolev, S. V., Babeyko, A. Y., \& Pons, M. (2022). Controls of the Foreland-Deformation Pattern in theOrogen-Foreland Shortening System: Constraints from High-Resolution Geodynamic Models. Earth andSpace Science Open Archive. https://doi.org/10.1002/essoar.10508507.2

Mackwell, S. J., Zimmerman, M. E., \& Kohlstedt, D. L. (1998). High-temperature deformation of dry diabase with application to tectonics on Venus. Journal of Geophysical Research: Solid Earth, 103(1), 975-984. https://doi.org/10.1029/97JB02671

Maloney, K. T., Clarke, G. L., Klepeis, K. A., \& Quevedo, L. (2013). The Late Jurassic to present evolution of the Andean margin: Drivers and the geological record. 
Marot, M., Monfret, T., Gerbault, M., Nolet, G., Ranalli, G., \& Pardo, M. (2014). Flat versus normal subduction zones: A comparison based on 3-D regional traveltime

tomography and petrological modelling of central Chile and western Argentina $\left(29^{\circ}-35^{\circ} \mathrm{S}\right)$. Geophysical increase in mantle viscosity. Nature Geoscience, $8(4)$, 311-314. https://doi.org/10.1038/ngeo2393

Martinod, J., Husson, L., Roperch, P., Guillaume, B., \& Espurt, N. (2010). Horizontal subduction zones, convergence velocity and the building of the Andes. Earth and Planetary Science Journal International, 199(3), 1633-1654. https://doi.org/10.1093/gj//ggu355

Marquardt, H., \& Miyagi, L. (2015). Slab stagnation in the shallow lower mantle linked to an Letters, 299(3-4), 299-309.

Muldashev, I. A., \& Sobolev, S. V. (2020). What Controls Maximum Magnitudes of Giant Subduction Earthquakes? Geochemistry, Geophysics, Geosystems, 21(9). https://doi.org/10.1029/2020GC009145

Murnaghan, F. D. (1944). The Compressibility of Media under Extreme Pressures. Proceedings of the National Academy of Sciences, 30(9), $244-247$. https://doi.org/10.1073/pnas.30.9.244

Neuharth, D., Brune, S., Glerum, A., Heine, C., \& Welford, J. K. (2021a). Formation of Continental Microplates Through Rift Linkage: Numerical Modeling and Its Application to the Flemish Cap and Sao Paulo Plateau. Geochemistry, Geophysics, Geosystems, 22(4), e2020GC009615-e2020GC009615. https://doi.org/10.1029/2020GC009615

Neuharth, D., Brune, S., Glerum, A. C., Morley, C. K., Yuan, X., \& Braun, J. (2021b). Flexural strike-slip basins. https://eartharxiv.org/repository/view/2439/ Oncken, O., Boutelier, D., Dresen, G., \& Schemmann, K. (2012). Strain accumulation controls failure of a plate boundary zone: Linking deformation of the Central Andes and lithosphere mechanics. Geochemistry, Geophysics, Geosystems, 13(12). https://doi.org/10.1029/2012GC004280

Oncken, O., Hindle, D., Kley, J., Elger, K., Victor, P., \& Schemmann, K. (2006). Deformation of the Central Andean Upper Plate System—Facts, Fiction, and Constraints for Plateau Models. The Andes, 3-27. https://doi.org/10.1007/978-3-540-48684-8_1

Pons, M., Sobolev, S., Liu, S., Neuharth, D. (2022): 2D geodynamic subduction model of the Central Andes. GFZ Data Services. https://doi.org/10.5880/GFZ.2.5.2022.001

Quinteros, J., \& Sobolev, S. V. (2013). Why has the Nazca plate slowed since the Neogene? Geology, 41(1), 31-34. https://doi.org/10.1130/G33497.1

Quinteros, J., Sobolev, S. V., \& Popov, A. A. (2010). Viscosity in transition zone and lower mantle: Implications for slab penetration. Geophysical Research Letters, 37(9), n/a-n/a. https://doi.org/10.1029/2010GL043140

Ramos, V. A., \& Folguera, A. (2009). Andean flat-slab subduction through time. Geological Society Special Publication, 327, 31-54. https://doi.org/10.1144/SP327.3

Ramos, V. A., \& Scientific, N. (2002). Flat-slab subduction in the Andes. Journal of South American Earth Sciences, 15(1), 1-2. https://doi.org/10.1016/s08959811(02)00011-1

Ranalli, G. (1997). Rheology of the lithosphere in space and time. Geological Society, London, Special Publications, 121(1), $19-37$. https://doi.org/10.1144/GSL.SP.1997.121.01.02

Ribe, N. M., Stutzmann, E., Ren, Y., \& Van Der Hilst, R. (2007). Buckling instabilities of subducted lithosphere beneath the transition zone. Earth and Planetary Science Letters, 254(1-2), 173-179.

Rose, I., Buffett, B., \& Heister, T. (2017). Stability and accuracy of free surface time integration in viscous flows. Physics of the Earth and Planetary Interiors, 262, 90100. https://doi.org/10.1016/J.PEPI.2016.11.007

Schellart, W. P. (2020). Control of Subduction Zone Age and Size on Flat Slab Subduction. Frontiers in Earth Science, 0, $26-26$. https://doi.org/10.3389/FEART.2020.00026

Schellart, W. P., \& Strak, V. (2021). Geodynamic models of short-lived, long-lived and periodic flat slab subduction. Geophysical Journal International, 226(3), 15171541. https://doi.org/10.1093/gji/ggab126

Schepers, G., Van Hinsbergen, D. J. J., Spakman, W., Kosters, M. E., Boschman, L. M., \& McQuarrie, N. (2017). South-American plate advance and forced Andean trench retreat as drivers for transient flat subduction episodes. Nature Communications, 8. https://doi.org/10.1038/NCOMMS15249

Sdrolias, M., \& Müller, R. D. (2006). Controls on back-arc basin formation. Geochemistry, Geophysics, Geosystems, 7(4). https://doi.org/10.1029/2005GC001090 Silver, P. G., Russo, R. M., \& Lithgow-Bertelloni, C. (1998). Coupling of South American and African plate motion and plate deformation. Science, 279(5347), 60-63. Sobolev, S. V., \& Babeyko, A. Y. (1994). Modeling of mineralogical composition, density and elastic wave velocities in anhydrous magmatic rocks. Surveys in Geophysics, 15(5), 515-544. https://doi.org/10.1007/BF00690173

Sobolev, S. V., \& Babeyko, A. Y. (2005). What drives orogeny in the Andes? Geology, 33(8), 617-620. https://doi.org/10.1130/G21557AR.1

Sobolev, S. V., Babeyko, A. Y., Koulakov, I., \& Oncken, O. (2006). Mechanism of the Andean Orogeny: Insight from Numerical Modeling. The Andes, 513-535. https://doi.org/10.1007/978-3-540-48684-8_25

Steinberger, B., \& Calderwood, A. R. (2006). Models of large-scale viscous flow in the Earth's mantle with constraints from mineral physics and surface observations Geophysical Journal International, 167(3), 1461-1481. https://doi.org/10.1111/J.1365-246X.2006.03131.X

Tan, E., Lavier, L. L., Van Avendonk, H. J. A., \& Heuret, A. (2012). The role of frictional strength on plate coupling at the subduction interface. Geochemistry, Geophysics, Geosystems, 13(10). https://doi.org/10.1029/2012GC004214 
Turcotte, D. L., Schubert, G., \& Turcotte, D. L. (2002). Geodynamics (2nd ed). Cambridge University Press.

van Hunen, J., van den Berg, A. P., \& Vlaar, N. J. (2004). Various mechanisms to induce present-day shallow flat subduction and implications for the younger Earth: A numerical parameter study. Physics of the Earth and Planetary Interiors, 146(1-2), 179-194. https://doi.org/10.1016/J.PEPI.2003.07.027

Wang, H., Currie, C. A., \& DeCelles, P. G. (2021). Coupling Between Lithosphere Removal and Mantle Flow in the Central Andes. Geophysical Research Letters, 48(16), e2021GL095075. https://doi.org/10.1029/2021GL095075

Widiyantoro, S. (1997). Studies of seismic tomography on regional and global scale.

Yáñez, G. A., Ranero, C. R., Von Huene, R., \& Díaz, J. (2001). Magnetic anomaly interpretation across the southern central Andes (32 $\left.{ }^{\circ} 34^{\circ} \mathrm{S}\right)$ : The role of the Juan Fernández Ridge in the late Tertiary evolution of the margin. Journal of Geophysical Research: Solid Earth, 106(B4), 6325-6345. https://doi.org/10.1029/2000JB900337 